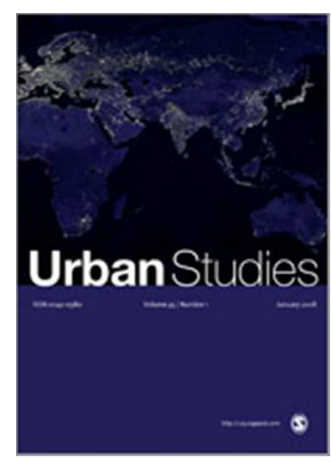

\title{
Risk, Commercialism and social purpose: Repositioning the English Housing Association sector
}

\begin{tabular}{|c|c|}
\hline Journal: & Urban Studies \\
\hline Manuscript ID & CUS-618-16-07.R1 \\
\hline Manuscript Type: & Article \\
\hline $\begin{array}{l}<b>\text { Discipline: Please select a } \\
\text { keyword from the following list } \\
\text { that best describes the } \\
\text { discipline used in your paper.: }\end{array}$ & Political Science \\
\hline $\begin{array}{l}\text { World Region: Please select } \\
\text { the region(s) that best reflect } \\
\text { the focus of your paper. } \\
\text { Names of individual countries, } \\
\text { cities \& economic groupings } \\
\text { should appear in the title } \\
\text { where appropriate.: }\end{array}$ & Western Europe \\
\hline $\begin{array}{l}\text { Major Topic: Please identify up } \\
\text { to two topics that best identify } \\
\text { the subject of your article.: }\end{array}$ & Housing \\
\hline $\begin{array}{r}\text { Please supply a further } 5 \\
\text { relevant keywords in the fields } \\
\text { below:: }\end{array}$ & $\begin{array}{l}\text { not-for-profit organisations, exposure to risk, not-for-profit, housing } \\
\text { organisations, G15 }\end{array}$ \\
\hline
\end{tabular}




\title{
Risk, Commercialism and Social Purpose: Repositioning the English Housing Association sector
}

\begin{abstract}
Originally seen as the 'third arm' of UK housing policy, the independent, not-forprofit housing association sector had long been seen as effective in 'filling the gap' where the state or market were unable to provide for households in need. Since the 1980s in particular, successive governments had viewed housing associations in favourable terms as efficient, semi-autonomous social businesses, capable of leveraging significant private funding. By 2015 in contrast, central government had come to perceive the sector as inefficient, bureaucratic and wasteful of public subsidy. Making use of institutional theory, this paper considers this paradigm shift and examines the organisational responses to an increasingly challenging operating environment. By focusing, in particular, on large London housing associations, the paper analyses their strategic decision-making to address the opportunities and threats presented. The paper argues that in facing an era of minimal subsidy, low security and high risk, the 2015 reforms represent a critical juncture for the sector. Housing organisations face a stark dilemma about whether to continue a strategy of 'profit for purpose' or to embrace an unambiguously commercial ethos. The article contends that the trajectory of decision-making (although not unidirectional) leads ultimately towards an increased exposure to risk and vulnerability to changes in the housing market. More fundamentally, the attempt to reconcile social and commercial logics is likely to have wider consequences for the legitimacy of the sector.
\end{abstract}


Keywords: not-for-profit organisations , exposure to risk , not-for-profit , housing organisations , G15

1

2

3

4

5

6

10

11

12

13

14

15

16

17

18

19

20

21

22

23

24

25

26

27

28

29

30

31

32

33

34

35

36

37

38

39

40

41

42

43

44

45

46

47

48

49

50

51

52

53

54

55

56

57

58

59

60 
Introduction

The need to manage risk has become a widely accepted feature of organisational environments within the public, private and voluntary sectors. Operating within a turbulent context, the not-for-profit housing sector has also struggled to balance the demands of commercialism and a need to retain a core social purpose (see for example, Morrison 2016a). Such tensions have been exacerbated by the removal of public subsidy, by changes to regulatory frameworks and an environment characterised by chronic uncertainty. As Czischke et al (2012) argue, greater knowledge is required about how not-for-profit housing organisations are responding to contemporary challenges, not only to ensure their business survival but also so that they continue to perform a critical role in providing decent homes to those who cannot afford market rents.

The above pressures are not unique to the UK. Increasing state withdrawal of funding in Australia, for example, has forced not-for-profit housing organisations to reconcile their involvement in commercial activities with a desire to retain their social mission (see Milligan et al 2012). The USA has seen not-for profit housing providers look towards commercial diversification to cross subsidise social activities (see Bratt et al, 2016) whilst in the Netherlands, housing associations in the 1990s diversified towards market housing sales to generate funding. The level of exposure to risk amongst Dutch housing associations, however, resulted in systemic failure, requiring State intervention and a return to the core social functions of managing and developing housing for low income groups (see Nieboer and Gruis, 2014; Van der Kuij et al 2016). 
Drawing on institutional theory, the purpose of this article is to consider how English housing associations (HAs) have responded to these contemporary pressures and how they have managed competing demands in an increasingly challenging environment. In focusing on large London HAs, the article considers how different obligations have helped re-define organisational purposes and strategic priorities. The article analyses how London HAs reconcile what appear to be incompatible aspirations between maintaining a social purpose alongside the demands of a commercial orientation, as they seek to cross subsidise their operations and to deliver Government housing targets $(\mathrm{G} 15,2016)$.

An understanding of how the large London HAs are responding to contemporary government pressures offers salient lessons for other HAs yet to undergo organisational change. By focusing on this critical juncture in the housing sector's history, the article not only highlights the trajectory of change for the HA sector but also considers the implications for the future of affordable housing provision in the modern welfare state. Lessons can also be applied to urban policy in other parts of the UK as well as to a wider international context. These lessons highlight key pressures and dilemmas confronting urban managers, as they struggle to provide services to local communities within an environment characterised by severe resource constraints.

The theory of institutional logics

Institutional theory offers a critical lens to analyse processes of organisational change, highlighting the rationale for decision-making, the capacity for autonomy, the 
relationship between voluntary and statutory sector agencies and changing power relations between service provider and local communities. The concept of 'institutional logics' in particular, a term introduced by Alford and Friedland (1985) has captured the contradictory practices and beliefs inherent in the institutions of modern western societies, helping to explain organising principles and providing social actors with 'a set of rules and conventions for deciding which problem gets attended to, which solutions get considered and which solutions get linked to which situation' (Thornton and Ocasio, 2008, p.114). The theory of institutional logics provides an important link between individual agency and cognitions on the one hand and socially constructed institutional practices and rule structures on the other. Logics provide a sense of identity, become embodied in practice, and are sustained and reproduced by cultural assumptions and political struggles with organisations both enabled and constrained by the prevailing institutional logic.

The institutional logics perspective invariably emphasises the existence of competing logics within a particular field and the ways in which different logics assume priority at different points in time. Whilst scholars have long emphasised the role of the State in regulating institutions, increasing attention has focused on the rise of a market logic and its effect on organisational behaviour and action (Scott 2001, p.51). Moreover, interest has grown on how the ascendency of a market logic has accompanied a decline in alternative logics, most notably relating to State-based regulation. Zuker (1987) contends that individuals and organisations rely on their understanding of this interplay between institutional logics in order to gain access to societal resources, aligning themselves with the prevailing logic in order to ensure their long-term survival. 
As Thornton and Ocasio (2008) contend, these struggles to ensure legitimacy, control over market competition and contestation of State rules and regulations shape organisations' logics of behaviour and action. Under conditions of neoliberalism, organisational status and power have become increasingly driven by economics, which has further embedded the market logic within the field (p.112). Portfolio and risk management status as well as expertise in finance, for instance, have become progressively valued as the market logic has gained prominence in welfare provision and public policy. Whilst the ascendency of the market logic does not necessarily imply a rejection of other logics it does require decision makers to switch their attention to issues and solutions that are consistent with the orientation of the dominant logic. Organisations thus follow suit, developing structural arrangements and production processes that conform and over time become institutionalised (Zuker, 1987).

At the same time, organisations react to their institutional environment in variegated ways, as they possess distinctive ideological values, identities, and styles of leadership, that influence their goals, purposes and logics of investment (Thornton and Ocasio, 2008). Consequently, they adopt different strategies to take advantage of opportunities afforded by the dominant market logic. As Scott (2001) contends, certain organisations are more effective in aligning themselves with dominant rules and conventions. Described as 'active players not passive pawns' (p.179) such organisations have the capacity to respond to external pressures in creative and strategic ways. Highlighting the way in which competing institutional logics are 
mediated and the organisational capacity for agency provides a critical avenue of research (Thornton and Ocasio, 2008, p.243).

A growing body of work has emerged within housing scholarship, seeking to understand how the theory of institutional logics can be applied to interpret the relationship between social and commercial goals (see for instance, Mullins, 2006; Sacranie 2012; Blessing, 2012; Czischke et al 2012, Morrison, 2016, a and b).

Since the late 1970 s and at an international level, the emergence of neoliberal welfare policies characterised by competition, entrepreneurialism, free markets and minimal State intervention has become an increasingly noticeable feature of the public policy agenda (Harvey, 2005, p.2). Under conditions of neoliberalism, the housing sector in general, and HAs in particular, have therefore experienced increasing levels of marketisation, exposure to risk; processes underpinned by the predominance of the financial sector (Hodkinson et al, 2013). In broad terms, housing organisations have been compelled to retreat from the traditional provision of subsidised rental housing, towards market renting and promoting varieties of homeownership.

The HA sector has also experienced growth in hybrid governance structures and development of diverse housing products to address the complex financial and regulatory challenges of the prevailing market logic (Morrison, 2016a). Moreover, sophisticated treasury management and financial portfolio analyses have been developed in response to the replacement of public with private funding and to exploit commercial opportunities (Morrison, 2016b; Tang et al 2016). Before examining the organisational responses to these competing demands, some context is given to 
explain the changing perception of the sector and to analyse the key structural constraints that have compelled English HAs towards a more commercial logic.

The changing landscape for English housing associations

Originally seen as the 'third arm' of UK housing policy, the purpose of the independent HA sector was to 'fill the gap' where the state or market was unable to provide for households in need (Malpass, 2000). Since the 1980s and influenced by neoliberal ideology, governments had viewed these organisations as preferred partners in developing and managing subsidised rental housing, in preference to supposedly bureaucratic and inefficient local authorities (Mullins and Murie 2006). As a consequence, the sector faced rapid expansion and following the Housing Act 1988 became the main providers of new social housing. Their ability to raise private finance enabled HAs to develop affordable housing and the sector expanded further through transfers of formerly local authority owned stock. Once viewed as an 'outstanding success', the sector was praised for its capacity to combine the disparate skills of entrepreneurialism and sound financial management (a market logic) with a commitment to a strong social purpose in providing good quality, affordable accommodation to households in need (Mullins and Pawson, 2010).

However, the privileged position of the housing association sector began to change, initially following the government's 2010 Comprehensive Spending Review, resulting in spending cuts of around $60 \%$ in 2015 , accompanied by a statement that government 
grant funding would end after 2018 (HCA 2015a) ${ }^{1}$. The 2010 Coalition government established an affordable housing programme, allowing HAs to charge up to $80 \%$ of local market rents, introduced fixed-term tenancies (under the Localism Act 2011) and restricted benefit payments (under the Welfare Reform Act, 2012).

The 2015 General Election marked a critical juncture for the sector following an unexpected Conservative majority government. Based on manifesto commitments, the government introduced proposals to extend the Right to Buy (RTB) to housing association tenants and proposed to restrict the ability of landlords to increase rents (by $1 \%$ per annum on social housing properties over a four year period) (HM Treasury, 2015). Whilst the RTB proposals proved highly contentious, the proposal to limit rent increases had a more profound impact on the sector, disrupting business plans, jeopardising income projections and threatening financial forecasts (HCA $2015 b)^{2}$.

In addition to the pressures of grant reduction, rent restrictions and welfare reform, the HA sector, for almost the first time, was subjected to significant censure from central government. Criticisms were directed at their inefficiency and lack of progress in meeting the Government's ambition to build 1 million new homes by 2020 (UK Parliament, 2016). These arguments were accompanied by a scarcely veiled threat that the government would act if housing associations failed to cooperate. As the then Chancellor of the Exchequer warned: 'They can either work with us...or there can be a more confrontational relationship' (Osborne, 2015). In what appeared to be a

\footnotetext{
${ }^{1}$ Government capital grant allocations were reduced from $£ 8.8 \mathrm{bn}$ to $£ 4.4 \mathrm{bn}$ in the HCA's 2010-14 Affordable Homes programme and to $£ 1.7 \mathrm{bn}$ in the 2015-18 programme (HCA 2015a)

${ }^{2}$ In 2013, the HA sector's rent formula of consumer price index (CPI) plus $1 \%$ for 10 years was agreed, so this U-turn in government policy in effect tore up previous rental guidance.
} 
sustained campaign, these criticisms were accompanied by profoundly hostile press attention. An article in the (centre-right) Spectator magazine referred to housing associations as 'the true villains of the property crisis' and described the sector as 'combining public sector lethargy and private sector greed' (Clark, 2015). An enquiry conducted by a national television channel (Channel 4 news) in 2015 was presented under the headline 'why are housing associations failing to build enough homes?' (Ebrahini 2015). Media reports also criticised 'low performing and highly paid' housing association CEOs - ‘£350,000 salary for Britain’s worst housing Chiefs’ as one headline expressed it (The Times, 18/3/16).

Housing associations therefore faced a challenging policy environment. Whilst the English HA sector has long diversified into commercial activities to cross subsidise their core social functions (see Malpass 2000; Mullins and Pawson 2010), contemporary organisations face stark decisions about how to reposition themselves in response to the above pressures. Given the scale of grant reductions the sector has chosen to diversify by developing more systematic strategies for market sale. However, such an approach inevitably implies greater exposure to risk, not least through fluctuations in the wider housing market and uncertainty in raising finance from capital markets (Wainwright \& Manville 2017). This new environment therefore presents acute tensions for the sector, both in terms of structural constraints and opportunities to exercise autonomy. As Morrison (2016a) argues, HAs need to develop a portfolio of commercial activity to fund their core businesses. At the same time they remain committed (for the most part) to a sense of social responsibility to existing (and future) tenants and are obliged to protect their assets from unnecessary risk. 
As institutional theory maintains, the conflicting regulatory logics commonly observed within public policy (Thornton and Ocasio, 2008) are clearly evident within the English housing association sector. Thus the Homes and Communities Agency (HCA) supports the establishment of unregistered profit-making subsidiaries to deliver HAs' commercial activities, such as market sales - such bodies are not constrained by charitable rules and can benefit from tax efficiencies. However, as these vehicles lack direct accountability (Morrison 2016a) HCA (2014; 2015a) government regulations specify that HAs must provide assurances that their social housing assets are not put at risk and that the public value within them is protected ${ }^{3}$. The sector therefore faces a challenging environment of relative autonomy, combined with continuing regulatory, financial and political pressures. In order to analyse these processes in greater depth, the next section examines how the major London HAs have responded to these pressures.

Research methods

Given the wide variation between HAs and organisational contexts, in order to analyse strategic decision-making, Gruis (2008) argues, it is important to select similar sized organisations operating in the same market conditions, to allow the external environment to be held relatively constant. For the present study, the sample was restricted to the large HAs (managing over 15,000 units each) operating in London (collectively known as the G15). Given unprecedented pressures to deliver

\footnotetext{
${ }^{3}$ HCA (2014) para. 5.1 sets out an explicit expectation that regulated parents ensure their nonregulated subsidiaries do not create excessive risk to regulated assets - there is therefore indirect accountability imposed on unregistered vehicles.
} 
new housing in the capital, in response to growing demands from existing and future tenants and the context of a market characterised by rising housing prices, the propensity to be market orientated in London is therefore extremely high (Savills 2016a).

The research entailed in-depth, semi-structured interviews with members of the G15 HAs' senior executive teams. The purpose of the interviews was to determine how individual organisations had revised their business plans, and in particular development programmes, in response to prevailing circumstances and to determine the rationale behind their strategic decision-making. The study aimed to identify the key risks of diversification and to consider how far a market logic can be reconciled with maintaining core social functions.

Given that senior managers would be expected to portray their organisations in a positive light, the interview responses were compared with documentary evidence to ascertain how far the claims could be supported or refuted by other forms of data. These data included analysis of HCA Global Accounts, which collect performance information about HAs' charitable registered status, including the extent to which surpluses made from diversification were used to fund non-social housing activities. Annual reports, financial accounts and company press releases were also analysed to consider the range of commercial (and non-commercial) activities undertaken within the group structures. Through this triangulation of qualitative and quantitative data, involving crosschecking and verification of senior managers' statements, the analysis examined taken-for-granted assumptions and values. In doing so, the research was able to highlight the relationship between the logics of social and commercial 
investment, their impact on strategic priorities and their influence on organisational behaviour (see also Morrison 2016a and b).

Strategic decision making within London housing associations

The G15 HAs represent the largest organisations working in the not-for-profit housing sector. They own and manage over 550,000 homes (accounting for $21 \%$ of the housing sector stock), provide accommodation for 1 in 10 Londoners and range in size from just over 15,000 properties (East Thames) to 71,700 properties (London $\&$ Quadrant). Historically they have been highly successful in their ability to generate funding; they leveraged $£ 15.5 \mathrm{bn}$ in private investment (representing $33 \%$ of sector’s net debt) and generated 47\% of the sector's overall surplus in 2015 (HCA 2016). They have an active development programme, having provided 16,000 affordable rental homes and 6,400 shared ownership properties between 2013 and 2016 (G15 2016). Nevertheless, the large London HAs acknowledge that they could increase output and have suggested that collectively their development programme could increase from 93,000 to 180,000 over 10 years in order to help deliver the government's national housing targets (Stothart, 2016).

An increase in development activity is undoubtedly needed in the London housing market where it is estimated that 50,000 homes per year are needed to keep pace with housing need - output in 2012-3 was 21,900 (Wilson, 2015). London has the highest housing prices in the country (the average housing price in 2016 was $£ 482,000$ in London, compared to $£ 234,000$ in England) (ONS, House Price Index) and increasingly high rent levels (an average of $£ 281$ per week, compared to $£ 145$ outside 
London) (London Housing Commission, 2016). The capital is therefore beset with chronic problems of affordability and whilst local authority development remains at historically low levels, the London market requires a dynamic and growing housing association sector that can respond to housing need.

As noted above, the HA sector has faced extensive public criticism in recent years, both for its lack of success in meeting housing need and for the level of remuneration offered to senior staff - although the salaries of the G15 Chief Executives (CEO) vary from $£ 155,000$ (East Thames) to $£ 300,706$ (Affinity Sutton). These salary figures do not necessarily equate with the size of organisation; CEO pay per home varies from $£ 3.69$ to $£ 10.25$ and even the trade magazine for housing professionals has questioned whether these salaries represent value for money (McCabe, 2016).

The G15 HAs are financially robust, with surpluses rising to a total of nearly $£ 1.5 \mathrm{bn}$ for 2015. Whilst this could be attributable to a favourable macroeconomic condition and historically low interest rates, such figures have encouraged the government to believe that the sector could become self-financing and should no longer be reliant on government subsidy (see Walker 2014, for example). In order to consider these and other issues further, the following sections examine how these HAs have responded to the specific challenges presented by an operating environment characterised by turbulent change.

Establishing a commercial logic 
As noted above, the dominance of a market logic has been a longstanding debate within the sector. However, given the scale of change following the 2010 and 2015 General Elections, the G15 respondents expressed little doubt that government reforms heralded a paradigm shift for the sector, illustrating how far decision-making was driven by exogenous factors. Whilst the Chancellor's rent reduction announcement came as an unpleasant shock, respondents were keen to suggest that they had anticipated the trajectory of change (choosing to highlight their relative autonomy). Hence, by the July 2015 Budget, 'the writing was on the wall' as one CEO commented, adding that 'all that happened is that the (government's) rent cut has made what we were intending to do all the more urgent.' In the words of another CEO 'we had to do what we could to make the business more efficient' ${ }^{4}$. Respondents were keen to emphasise how seriously they had taken the efficiency agenda (even before the centrally imposed rent reduction): 'I have spent the last three years really driving down operating costs' as one CEO commented. For many, the external environment presented a valuable opportunity for organisational change. For example:

In a way it takes the external pressure of radical cost cutting driven by government to make organisations really think... But you need to be careful what you wish for. I wouldn't encourage any more radical action, but I think some good will come from it (Interview)

\footnotetext{
${ }^{4}$ Projected income losses from an impact of rent reductions over four years varied by organisations, for instance AmicusHorizon ( $£ 39 \mathrm{~m})$, Affinity Sutton ( $£ 38 \mathrm{~m})$ and A2 Dominion ( $£ 53 \mathrm{~m})$.
} 
This commercial logic was manifested in a number of ways, the first of which was an increased reliance on property sales income as a proportion of turnover. Table 1 highlights the extent to which sales from non-social housing development and first tranche sales of shared ownership housing products has grown for each of the G15 HAs. $^{5}$ Whilst the share of this development activity as a proportion of total turnover varied by organisation, from Catalyst (43\%) to Circle (10\%) in 2015, this upward trend indicates the degree to which the G15 has become increasingly reliant on nonsocial housing development. All the CEOs interviewed acknowledged that they were looking to increase the proportion of market sales within their development programmes as grant diminished, arguing that the cash receipts generated were needed to cross subsidise the delivery of affordable homes. 'I think it will play an increasingly important role in how new homes are funded. If you move away from a grant model you have to look at all sources of capital' as one CEO suggested.

A second illustration of a dominant commercial logic was an increased exposure to risk, as HAs were subject to cyclical changes in the market. Despite London benefiting from above average housing price rises, this market exposure increased their vulnerability to housing market fluctuations. Delays in initiation and completion of schemes, slowdowns in sales, reductions in market prices and failures to achieve projected sales incomes represented threats to business plan assumptions and to an ability to comply with loan covenants. "Even London is not impervious to shocks", as one CEO remarked.

\footnotetext{
${ }^{5}$ N.B The HCA Global accounts 2015 for the first time recorded commercial diversification activities of HAs' registered entities (HCA 2016). This dataset under-records individual organisation's commercial activities carried out in non-registered subsidiaries (e.g. Peabody Group's building for sale $(132,883)$ was nearly ten times the amount undertaken in its registered Trust $(13,858))$.
} 
A greater reliance on cross subsidy from commercial activities resulted in increasingly sophisticated approaches to financial risk modelling to accommodate a complex business environment. However, G15 members believed they were well placed to address these challenges. The main strength of these large London HAs was their asset bases that offered a strong competitive advantage and leverage for borrowing: 'developers do not have the same equity base' as one respondent expressed it. Although a reliance on market sales generated risk if property prices and values fell, many organisations had established contingency arrangements, for example by changing the tenure profile to shared ownership, private renting, or even affordable housing if necessary. Unlike private developers, HAs were in a position where they could maintain their existing properties and defer making a profit 'diversification allows us these options'. As one respondent explained:

the more you move towards this self-funding model and move away from government grant the more you become pro-cyclical. Whereas the grant funding model was effectively a counter-cyclical model... This model is clearly about big market exposure, so [we are] making sure we have plans and the right prudential limits around how much exposure we have at any given time to keep the rating agencies and funders happy and to make sure the business is protected.

Nevertheless, as Scott (2001) contends, alignment with the dominant market logic can be precarious: 'If the market falls, the cross subsidy element would be reduced at a stroke', a CEO argued. Guarantees that there would be no impairment risks to social housing assets were therefore necessary as these complex, hybrid organisations moved towards a market logic, albeit one which carried not only financial but also 
reputational risks. Whilst there was a clear opportunity cost of undertaking commercial activities, a number of organisations also saw this new direction of travel as an opportunity to be seized, as the CEO of Genesis Housing Association argued publicly after the July 2015 Budget announcement:

We could become something different. I don't know where this will lead...There are great opportunities opening up to reduce some of the regulation we go through... putting your head in the sand means that someone tramples all over you. I don't want Genesis to do that. I want Genesis to be in the forefront of change (Neil Hadden, interview, quoted in Inside Housing, $31 / 7 / 15)$.

These new risk factors required changes in organisational structures and governance arrangements and many HAs had undergone fundamental restructuring and developed new business models (see Figure 1 which depicts a typical G15 group structure). Whilst most of the HAs had established complex, hybrid group structures, pursued innovative borrowing techniques and created a range of non-charitable subsidiaries to carry out market activities prior to the July 2015 Budget announcement, much higher expectations were now placed on their commercial operations. At the same time, the governing boards were required to have higher-level skills to understand and recommend business decisions from non-social housing activities as well as the capacity to analyse the significance of new interdependencies within the organisation. These new skills implied that Board members were likely to be recruited on the basis of their private sector, financial management experience, rather than as local community representatives. 
This commercial logic not only affected decision-making, organisational strategies and Board membership, it also influenced the location of development activity. In the words of one respondent, the key to minimise risk was to 'buy land wisely and diversify geographically', which meant that due to difficulties of developing within inner London, activities tended to focus on so-called 'zone 3' (outer London) boroughs. At the same time, these constraints also offered considerable opportunity, as HAs were considered to be 'attractive partners' by private developers, given their ability to cope with risk. A number of respondents maintained that joint ventures would become more significant within this changed environment, and they in particular made development within inner London areas more feasible (in theory at least) - 'it allows more and more to happen' as one commented. Respondents also welcomed an increased autonomy to take decisions, often complaining of continuing government interference. In the words of one CEO 'I'd love to be in a position in some respects to pay back all the grant, because then I would be truly independent' (Interview).

The final component of a commercial logic was illustrated by the way that HAs were seeking to change the socio-economic composition of their residents. All respondents agreed that the tenure mix would have to change following reductions in subsidy and cuts in rental incomes on their social housing properties. As the G15 collectively announced to the CLG (2015) Select Committee (G15 2015):

The Government has set the HA sector a big challenge by cutting rents. We are being asked to deliver development with less funding... Ultimately the 
G15 are net borrowers every year...Smaller surpluses will result in reduced supply of new homes... We are determined to keep developing but it is highly likely that the number of affordable homes for rent will be a smaller proportion of overall building (p.1)

One respondent, for example, explained that before the rent cut their development programme was predicated on a third affordable housing, a third shared ownership and a third market rentals and market sales - 'now it is 10\% affordable housing, 50\% shared ownership and 40\% market sales and rented'. Many of the other G15 organisations mirrored this trend, with the CEOs justifying their course of action in order to maintain the economic viability of their development programmes.

\section{Retaining a social purpose}

Whilst a commercial logic clearly played an increasingly dominant role in discussions of organisational purpose, senior managers and Chief Executives argued that they remained committed to an organisational purpose driven by a social logic, regardless of economic contingencies. As shown in Table 2, turnover from social housing lettings constitutes a high proportion of total turnover in each of the G15 organisations, varying from Catalyst (68\%) to Circle (98\%) in 2015. As large London HAs, these organisations benefited greatly from the high gross book value of their portfolio, with figures well above the national average. As a consequence, they were heavily reliant upon borrowing against their social housing assets to fund development programmes. Table 2 indicates how the gross book value of assets ranged from over $£ 5.5 \mathrm{bn}$ for London \& Quadrant (with the largest social housing 
stock) to just under $£ 1.2 \mathrm{bn}$ (in the case of Network, with the lowest number of properties). These figures illustrated how the sector was becoming increasingly reliant on these historic, social housing assets to raise capital funding. However, this capital funding was largely devoted to market housing, raising questions about how far public assets were used to finance entrepreneurial activity.

Whilst the reliance on turnover from social housing lettings continued to be seen as the core business for the London HAs, as seen above the reductions in rental income following the July 2015 Budget announcements removed significant capacity from their business plans. Nevertheless, respondents stressed that they had adopted a pragmatic approach, describing their strategy as an 'adaptive mechanism' to enable cross subsidy which would enable them to realise their social purpose. At the same time they argued: 'We were clear that what we didn't want to do is stop doing some of our core activities'. This CEO explained the distinctive purpose of the organisation as follows:

$$
\begin{aligned}
& \text { the thing that differentiates us is that we are clear that we do not want financial } \\
& \text { pressures to drive a reduction in service quality. Whether withdrawing from } \\
& \text { anti-social behaviour (ASB) initiatives, from community development activity, } \\
& \text { resident involvement or jobs and training.... If anything these things become } \\
& \text { even more important as communities struggle with welfare cuts and poverty. }
\end{aligned}
$$

The difficulty was that the sector was at the same time repositioning itself to focus on a clear set of market driven priorities. Thus, whilst some emphasised that they would continue to provide core services, many had chosen to end their involvement in 
activity such as providing supporting housing for vulnerable groups, given the uncertainty surrounding future sources of income. Hence

we need clarity from Government and we cannot justify putting internal subsidies into these extra care schemes - $£ 150,000$ subsidy is needed per unit and these schemes just do not stack up. We are disappointed as there is still obviously a need for them.

\begin{abstract}
All organisations interviewed emphasised, however, that they would continue to fund additional 'housing plus' work, which was seen as a 'community investment' despite often being a loss-making activity (in monetary terms). As Table 2 indicates, four of the organisations recorded a deficit from their non-core ('other') social housing activities, which continued to be seen as important. In the words of one respondent: 'if we don't provide these community investments, who will? It is part of our social mission'. This social logic formed an important source of motivation for many in the sector; 'we have dedicated staff. We make money on other aspects of our business; why cut back on this aspect?'
\end{abstract}

As a finance director commented, providing debt advice, employment and training opportunities made financial sense as 'to make the community more economically active is better for us and better for the community'. For many respondents, the social value of this activity not only could be translated into financial value, but also had considerable multiplier effects. Whilst the core social purpose remains providing and managing subsidised rental housing, the broader housing plus role is 'what the sector does', as this director argued. Although community investment would inevitably 
remain a very small proportion of total turnover, respondents argued that the expenditure 'would not be touched', despite a recalibration of business plans to take into account the rent reductions ${ }^{6}$.

Moreover, all of the G15 respondents contacted expressed a continued strong commitment to sub-market rented housing, albeit at reduced levels: 'It is all very well for government policy to be wholly based on home ownership but they ultimately need subsidised rental housing - whether they like it or not'. Respondents expressed a firm commitment to affordable sub-market rented housing. As one CEO explained

We have a new development strategy, but what I can say for sure is that there will be a proportion of the programme with rents around current social rent levels (around $45 \%$ of market levels) to ensure that we can offer properties to people who are on benefits, nominated from local authorities.

Respondents were keen to argue that there was no inherent contradiction between social and commercial logics. They are 'not mutually exclusive' and 'they are entwined', represented common responses. Yet they were also clear to stress that their mission was now to meet 'a range of housing need' rather than simply accommodating low income households. This commitment to social purpose represented sincerely held views. However, there remained the question of how far the sector could continue to sustain loss-making activity within an environment characterised by competition, financial risk and marketisation. What seemed clear was that there was a disjuncture between a rhetoric of social purpose and the reality of

\footnotetext{
6 The G15's community and economic development programmes were worth over $£ 40 \mathrm{~m}$ in total in 2015 (G15 2016).
} 
commercial business strategy. Whilst the G15 HAs' revised organisational direction responds to affordability pressures experienced by a wide spectrum of residents, there is an opportunity cost in diverting attention away from housing for those in greatest need. The next section therefore subjects the above claims to critical scrutiny.

\section{Discussion}

Although the changes are not unidirectional, the growth and prevalence of neoliberalism in housing policy has not only led to a market logic to assume primary significance, but has been supported by a regulatory agenda, particularly within the UK that has emphasized sound financial management as the key (if not sole) criterion for success (Hodkinson et al 2012). This market logic has in turn assumed paramount importance in determining organisational behavior and actions, as witnessed in HA sector (as well as in wider welfare policy). In considering both structural constraints and the capacity for agency, institutional logics perspective offers a way to examine how organisations can take advantage of the prevailing logic to further elaborate, manipulate and use to their own advantage (Thornton and Ocasio, 2008), within certain parameters at least. The empirical results from this study support these arguments.

The responses from the G15 London HAs' senior managers suggested a collective consensus about the importance of retaining a strong social purpose. However, scrutiny of the business models applied represented a fundamental challenge to this ethos. In an attempt to ensure their long run survival, the large London HAs had not only aligned themselves with the dominant market logic, they also had to 'switch their 
attention to issues and solutions...that were consistent with (its) orientation' (Zuker 1987), namely development for outright market sale that over time would constitute a significant proportion of their development programmes. Making use of the market rhetoric to justify their re-defined business purpose and chosen course of action (Thornton \& Ocasio 2008), the G15 London organisations had attempted to position themselves as 'active players' (Scott 2001, p.179) in delivering Government housing targets that prioritise homeownership. These developments indicate the London HAs' direction of travel towards the idea of what they liked to term 'profit for purpose' (Mullins and Pawson 2010).

London HAs have specific advantages to pursue market-orientated strategies, as a result of their extensive unencumbered asset base (containing individual properties worth several £million). This asset base provided considerable borrowing capacity and allowed large surpluses to be produced from social housing lettings and remains the key means of differentiation between London and other UK areas. Moreover, in response to government reforms since at least 2010, the G15 HAs have led the way in commercial diversification strategies, placing considerable emphasis on a strong business culture, justified as helping to optimise social outcomes. All of the organisations had plans to increase the proportion of market sales and were becoming progressively more reliant on the income generated from these activities in future business plans. As they move towards more complex hybrid group structures with a greater level of commercial activity in non-charitable subsidiaries, this business model will inevitably increase their risk exposures. 
However, as the tenure mix changes in new schemes and the amount of sub-market rental provision falls to allow development programmes to remain commercially viable, tensions will become more explicit as the HAs seek to reconcile competing social and commercial goals. Inevitably, they will face difficult choices in meeting their social duties to house the lowest income households in London, whilst a market logic compel organisations to abandon their social roots, as they widen their resident profile and divert their attention to building housing for outright sale.

Notwithstanding the above points, some have chosen to view such tensions as strengths. HAs have been described as using 'chameleon-like activity' (Blessing, 2012), to avoid undue dependency on public subsidy, whilst harnessing an ability to access private financial markets (Mullins and Murie, 2006). Their status as hybrid institutions has in effect enabled them to take advantage of both government subsidy and private finance. Many of the assumptions that had underpinned HAs' operations, however, have now been removed - for example, generous government subsidy, political consensus about their positive contribution to housing delivery and local community support. As Murtha (2015) maintains, 'the Government has forced their hand' (p.1). The sector has a duty to respond not only to the government's efficiency drive but also to increase their capacity to deliver new housing in order to ensure not only their long run survival but also their legitimacy in the face of wider public criticism. Whilst the London HAs have plans to increase their output and respond in particular to the Capital's housing crisis, diverting attention to meeting a 'range of housing need' rather than concentrating on providing for the lowest income households within London, is likely to have serious consequences for the most 
vulnerable groups and those with the least ability to pay (London Housing Commission, 2016).

\section{Conclusions}

Internationally, the historical development of the not-for-profit housing sector created an institutional environment where organisations shared a common goal to provide low-income groups with decent housing at a price they could afford. In the UK as elsewhere, the policy framework since the 1980s has progressively weakened this consensus and a sector (which was always heterogeneous) has been transformed under conditions of neoliberalism by changes in exposure to market risk, heralding new governance arrangements and business models (Mullins et al 2012).

By framing the way in which contemporary policy uncertainty manifests itself in organisational decisions, institutional theory helps to explain how and why the large London HAs have been transformed into complex businesses extensively driven by a market logic motivated by State withdrawal. Organisations' strategic priorities are in effect manifestations of, and legitimated by, the institutional logics they face (Thornton \& Ocasio 2008). Moreover, the way in which these HAs have responded to external pressures offers salient lessons for organisations yet to restructure and diversify into commercial activities so that they too become more self financing and secure their long term survival.

The paper also brings to the fore wider questions and raises further avenues for research. What future is there for subsidised market rented housing, particularly 
within a city like London where affordability problems remain unprecedented and likely to worsen? What can these organisational changes tell us about the direction of travel for housing policy in general in England and for the housing association sector in particular? The combination of political pressure to promote owner occupation and economic pressures to reduce funding, mean that a market-oriented trajectory is set to continue and the sector is likely to become divided between two categories of not-forprofit housing organisation. Those that are 'active players' (Scott 2001, p.179), using the market rhetoric to their advantage look to be rewarded by government, whilst those that resist or are passive are likely to be left behind (NHF 2016). The trend towards greater merger activity within the UK housing sector, as the active organisations in particular pursue their growth strategies, is an issue that will provide scope for future research study.

When Dutch housing associations adopted an ambiguously commercial logic, they soon foundered, eventually requiring State intervention (Nieboer and Gruis, 2014, Van der Kuij et al 2016). Given this context, the extent to which the English HA sector can continue to pursue a distinctive social purpose, delivering affordable housing to those with least ability to pay, may therefore be in some jeopardy, raising questions about the wider legitimacy of the housing association sector. As the organisations move inexorably towards a market logic, an inability to respond to the needs of households, particularly those most vulnerable to London's housing crisis, is likely to have wider implications for urban policy. At the same time, in light of the 2016 UK Referendum result to leave the EU, exposure to risk and vulnerability to changes in the housing market may well be accentuated (NHF 2016b, Savills 2016b). 


\section{References}

Alford, R. and Friedland, R. (1985) Powers of Theory: Capitalism, the State, and Democracy Cambridge: Cambridge University Press.

Apps, P. (2015) 'Large association stops building cheap rented homes'. Available at: http://www. insidehousing.co.uk/business/development/land- and-construction/largeassociation-stops-building- cheap-rented-homes/7011045.article.

Blessing, A. (2012) 'Magical or monstrous? Hybridity in social housing governance.' Housing Studies 27 (2), pp189-207

Binder, A. (2007) 'For love and money: Organizations' creative responses to multiple environmental logics', Theory and Society. 2007, 36(6), pp.547-71.

Bratt, R., Rosenthal, L. \& Wiener, R. (2016) 'Challenges facing social housing organisations in the US: Insights from Boston and San Francisco Bay area leaders', paper presented to European Network of Housing Research Annual Conference, Belfast, 2016

Clark R (2015) 'Why housing associations are the true villains of the housing crisis' http://www.spectator.co.uk/2015/07/housing-associations-have-failed-to-buildhouses/

Czischke, D, Gruis, V. and Mullins, D (2012) 'Conceptualising social enterprise in housing organisations', Housing Studies 27 (4) pp.418-437

Ebrahini H (2015) 'Why are housing associations failing to build enough homes?' http://www.channel4.com/news/housing-associations-homes-property-bob-blackmandavid-orr

G15 (2016) G15 submission to the CLG select committee enquiry http://g15london.org.uk/g15s-submission-to-the-glc-select-committee-enquiry/ 
G15 (2016) Our housing offer for London http://g15london.org.uk/aboutus/our_housing_offer_for_london/

Gruis, V. Nieboer, N. and Thomas, A (2004) 'Strategic asset management in the social rented sector: approaches of Dutch and English housing associations', Urban Studies, 41 (7) pp.1229-1248

Gruis, V. (2008) 'Organisational archetypes for Dutch housing associations', Environmental and Planning C, 26, pp.1077-1092

Gruis, V. and Nieboer, N. (2007) 'Government regulation and market orientation in the management of $\mathrm{SH}$ assets: limitations and opportunities for European and Australian landlords', European Journal of Housing Policy 7 (1) pp.45-62

Hodkinson, S., Watt, P. and Mooney, G. (2013) 'Introduction: Neoliberal housing policy - time for a critical re-appraisal?' Critical Social Policy, vol.33, issue 1, pp.316

Harvey, D. (2008) A Brief History of Neoliberalism Oxford: Oxford University Press Homes and Communities Agency HCA (2014) Regulating the Standards 2014, London: HCA

HCA (2015a) Affordable Homes programme 2015-18: Guidance and allocations, London:

HCA (2015b) Sector Risk Profile 2014, London: HCA

HCA (2016) Global accounts, London: HCA

Her Majesty Treasury (HM) (2015) Summer Budget 2015 https://www.gov.uk/government/topical-events/budget-july-2015

Lees, L. (2013) 'The urban injustices of New Labour's "new urban renewal": the case of the Aylesbury Estate in London', Antipode, Article first published online: 3 May 2013, DOI: 10.1111/anti.12020 
London Housing Commission (2016) Building a New Deal for London: First Report of the London Housing Commission London: IPPR

McCabe J (2015) 'Chief Executive salary survey' http://www.insidehousing.co.uk/inside-housing-chief-executive-salary-survey2015/7011635.article Malpass, P. (2000) Housing Associations and Housing Policy: A Historical Perspective London: Palgrave Macmillan

Milligan, V. Hube, K. and Davison, G. (2012) Understanding Leadership, Strategy and Organisational Dynamics in the Not-for-profit Sector, Sydney: Australian Housing and Urban Research Institute

Morrison, N. (2013) 'Meeting the decent homes standard: London housing associations' asset management strategies', Urban Studies, 50 (2) pp.2569-2587

Morrison, N (2016a), 'Institutional logics and organisational hybridity: English housing associations' diversification into the private rented sector' Housing Studies, $31(8)$ pp.897-915

Morrison, N (2016b), 'Selling the family silver? Institutional entrepreneurship and asset disposal in the English HA sector' Urban Studies DOI:

$10.1177 / 0042098016653874$

Mullins, D. (2006) Competing institutional logics? Local accountability and scale and efficiency in an expanding non-profit housing sector, Public Policy and Administration, 21 (6) pp.6-24

Mullins, D. and Jones, T. (2016) 'From contractors to the state' to 'rptectors of public value'? Relations between non-profit housing hybrids and the state in England', Voluntary Sector Review, 6,3, pp.261-83. 
Mullins, D. and Murie, A. (2006) Housing Policy in the UK Basingstoke: Palgrave Macmillan

Mullins, D. and Pawson, P. (2010) 'Housing associations: agents of policy or profits in disguise?' in D. Billis (ed) Hybrid Organisation and the Third Sector. Challenges for Practice, Theory and Policy Basingstoke: Palgrave Macmillan pp.197-218

Mullins D, Czischke D, and Van Bortel G (2012) 'Exploring the meaning of hybridity and social enterprise in Housing organisations’ Housing Studies 27 (4) pp.405-417

Murtha, T. (2015) The housing association that will no longer build homes for the poor http://www.theguardian.com/housing-network/2015/aug/07/housingasssociation-no-longer-build-homes-poor-genesis

National Housing Federation (2016a) A look ahead at 2016 https://www.housing.org.uk/blog/a-look-ahead-at-2016-in-the-national-housingfederation-part-1/

NHF (2016b) Briefing: the vote to leave the EU: Considerations for housing associations

http://s3-eu-west1.amazonaws.com/pub.housing.org.uk/The_vote_to_leave_the_EU__considerations_for_housing_associations.pdf

Nieboer, N and Gruis, V (2014) 'Shifting back - changing organisational strategies in Dutch Social Housing', Journal of Housing and Built Environment 29 pp1-13

Osborne G (2015) Evidence to the House of Lords Economic Affairs Committee http://www.parliament.uk/business/committees/committees-a-z/lordsselect/economic-affairs-committee/news-parliament-2015/0

Pawson, H. and Mullins, D. (2010) After Council Housing: Britain's New Social Landlords London: Palgrave Macmillan 
Powell, W. and DiMaggio, P. (1991) (eds) The New Institutionalism in Organizational Analysis, Chicago: University of Chicago Press

Sacranie, H. (2012) 'Hybridity enacted in a large English housing association: a tale of strategy, culture and community investment', Housing Studies 27 (4) pp.533-552 Savills (2016a) London prime residential market http://www.savills.co.uk/research/uk/residential-research/land-indices/prime-london$\underline{\text { index.aspx }}$

Savills (2016b) The impact on the mainstream market: Brexit briefing http://pdf.euro.savills.co.uk/uk/residential---other/brexit-briefing--the-impact-on-themainstream-market.pdf

Scott, W. (2001) Institutions and Organisations $2^{\text {nd }}$ edition, London: Sage

Stothart, C. 'G15 adopts rating agency risk approach', http://www.socialhousing.co.uk/g15-adopts-rating-agency-risk-approach-to-reach180k-home-plan/7014240.article

Tang, C., Oxley, M. and Mekic, D., 2016. Meeting commercial and social goals: institutional investment in the housing association sector. Housing Studies, pp.1-17 Thornton, P. and Ocasio, W. (2008) 'Institutional logics' in R. Greenwod, C. Oliver, K. Sahlin and R. Suddaby (eds) The Sage Handbook of Organisational Institutionalism, London: Sage, pp.99-139.

The Times (2016) $£ 350,000$ salary for Britain's worst housing Chiefs http://www.thetimes.co.uk/tto/news/uk/article4716264.ece Van der Kuij R, Gruis V \& Nieboer N (2016) 'Exploring congruency within organisational change in Dutch Housing Associations, paper presented to European Network of Housing Researchers Annual Conference, Belfast 
Walker, B. (2014) Freeing Housing Associations: Better Financing, More Homes London: Policy Exchange

Watt, P. (2013) 'It's not for us: Regeneration, the 2012 Olympics and the gentrification of East London', City, 17 (1), pp.99-118

UK Parliament (2016) Planning for Housing, London: The Stationary Office

http://researchbriefings.parliament.uk/ResearchBriefing/Summary/SN03741

Wainwright, T. and Manville, G. (2017) 'Financialization and the third sector: Innovation in social housing bond markets' Environment and Planning A $0308518 X 16684140$

Wilson, W. (2015) Meeting London's Housing Need London: House of Commons

Wooten, M. and Hoffman, A. (2008) 'Organisational fields: Past, present and future' in R. Greenwod, C. Oliver, K. Sahlin and R. Suddaby (eds) The Sage Handbook of Organisational Institutionalism, pp.130-148.

Zuker, L. (1987) 'Institutional theories of organisation', Annual Review of Sociology 13 pp.443-464 
Table 1 G15 HAs' first tranche sales and non-social housing development activities: income 2014/15

\begin{tabular}{|c|c|c|c|c|c|c|c|c|}
\hline & \multicolumn{2}{|c|}{$\begin{array}{l}\text { Total } \\
\text { turnover }\end{array}$} & \multicolumn{2}{|c|}{$\begin{array}{l}\text { First tranche } \\
\text { sales }\end{array}$} & \multicolumn{2}{|c|}{$\begin{array}{l}\text { Non-social } \\
\text { housing } \\
\text { development }\end{array}$} & \multicolumn{2}{|c|}{$\begin{array}{l}\text { Development } \\
\text { activities share } \\
\text { of total } \\
\text { turnover }\end{array}$} \\
\hline & $f m$ & $\begin{array}{l}\text { Change } \\
\text { on } \\
\text { year } \%\end{array}$ & $f m$ & $\begin{array}{c}\text { Change } \\
\text { on year } \\
\%\end{array}$ & $f m$ & $\begin{array}{c}\text { Change } \\
\text { on year } \\
\%\end{array}$ & $2014 / 15$ & $2013 / 14$ \\
\hline L\&Q & 642 & 11 & 33.0 & 6 & 204 & 21 & 37 & 34 \\
\hline Circle & 412 & 14 & 14.5 & 224 & 27.2 & 1,600 & 10 & 2 \\
\hline Notting Hill & 381 & 28 & 68.5 & 111 & 76.8 & 55 & 38 & 27 \\
\hline $\begin{array}{l}\text { Affinity } \\
\text { Sutton }\end{array}$ & 430 & 34 & 40.1 & 153 & 89.8 & 309 & 30 & 12 \\
\hline Hyde & 326 & 16 & 34.5 & 60 & 52.2 & 41 & 27 & 21 \\
\hline A2Dominion & 297 & 9 & 12.4 & -42 & 75.8 & 42 & 30 & 27 \\
\hline Genesis & 282 & 6 & 22.2 & 76 & 13.8 & 50 & 13 & 8 \\
\hline $\begin{array}{l}\text { Family } \\
\text { Mosaic }\end{array}$ & 230 & -6 & 10.2 & -52 & 29.2 & -27 & 17 & 25 \\
\hline Peabody & 223 & 35 & 14.5 & 113 & 10.4 & -7 & 11 & 11 \\
\hline Catalyst & 212 & 23 & 40.2 & 163 & 50.6 & 27 & 43 & 32 \\
\hline Network & 190 & 21 & 24.6 & 6 & 28.4 & 506 & 28 & 18 \\
\hline $\begin{array}{l}\text { Southern } \\
\text { Housing }\end{array}$ & 175 & 10 & 14.9 & 113 & 13.5 & 5 & 16 & 12 \\
\hline East Thames & 146 & -17 & 15.5 & 15 & 33.9 & -41 & 34 & 41 \\
\hline Metropolitan & 240 & -6 & 6.4 & -35 & 9.8 & -65 & 7 & 15 \\
\hline Amicus & 161 & 1 & 4.3 & 1 & - & - & 3 & 3 \\
\hline
\end{tabular}

(source: adapted from Social Housing, 2016) 
Table 2 G15 HAs' social housing businesses (2015)

\begin{tabular}{|l|r|r|l|l|l|}
\hline & $\begin{array}{l}\text { Social } \\
\text { housing } \\
\text { units } \\
\text { managed } \\
\text { book } \\
\text { value of } \\
\text { housing } \\
\text { properties } \\
\text { (Ebn) }\end{array}$ & $\begin{array}{l}\text { Gross } \\
\text { from } \\
\text { social } \\
\text { housing } \\
\text { lettings } \\
\text { (Em) }\end{array}$ & $\begin{array}{l}\text { Turnover } \\
\text { from } \\
\text { social } \\
\text { housing } \\
\text { lettings } \\
\text { as a \% of } \\
\text { total } \\
\text { turnover }\end{array}$ & $\begin{array}{l}\text { Total } \\
\text { other* } \\
\text { social } \\
\text { housing } \\
\text { activities } \\
\text { (surplus/ } \\
\text { deficits) } \\
\text { (E000) }\end{array}$ \\
\hline Hyde & 41,772 & 2.63 & 168 & 93 & $(13,507)$ \\
\hline L\&Q & 28,460 & 5.53 & 389 & 89 & 6,090 \\
\hline Genesis & 26,700 & 2.89 & 234 & 71 & 3,800 \\
\hline Notting Hill & 26,700 & 2.15 & 171 & 89 & $(1,100)$ \\
\hline Southern & 23,969 & 3.06 & 136 & 87 & 3,879 \\
Housing & 22,617 & 3.06 & 283 & 93 & $(4,660)$ \\
\hline Affinity Sutton & 20,893 & 2.22 & 183 & 86 & 1,020 \\
\hline Family Mosaic & 18,633 & 1.46 & 146 & 68 & $(803)$ \\
\hline AmicusHorizon & 13,729 & 1.04 & 79 & 67 & 2,505 \\
\hline East Homes & 12,737 & 2.38 & 175 & 87 & 11,324 \\
\hline Metropolitan & 11,892 & 1.92 & 112 & 89 & 11,728 \\
\hline Catalyst & 10,623 & 1.46 & 113 & 76 & 8,040 \\
\hline Peabody & 8,022 & 1.16 & 184 & 84 & 3,692 \\
\hline A2Dominion & 7,417 & 1.49 & 93 & 98 & 2,982 \\
\hline Circle & 5,839 & 1.19 & 69 & 72 & 9,298 \\
\hline Network & 1,097 & 0.09 & 6.7 & 80 & 73,143 \\
\hline England average & 361,973 & 30.1 & 2.206 & & \\
\hline England total & & & & & \\
\hline
\end{tabular}

(source: authors compiled from HCA 2016)

*'Other' social housing activities consist of community investment e.g. employment and training initiatives, apprenticeships, debt advice etc to tackle social exclusion 
Figure 1: An illustration of a G15 hybrid group structure

1

2

3

4

5

6

7

8

9

10

11

12

13

14

15

16

17

18

19

20

21

22

23

24

25

26

27

28

29

30

31

32

33

34

35

36

37

38

39

40

41

42

43

44

45

46

47

48

49

50

51

52

53

54

55

56

57

58

59

60

** Build for sale and shared ownership undertaken within a non-charitable subsidiary e.g. Notting Hill development 1td/A2 Dominion FABRICA/GenInvest ltd/Family Mosaic homeownership ltd/ Peabody Enterprise Ltd/ L\&Q New Homes ltd etc.

(source: authors adapted from G15 company reports) 